\title{
Trends of climate change at the mid-low Nazas-Aguanaval inland basin based on a geographical approach
}

\section{Tendencias de cambio climático para la parte media-baja de la cuenca endorreica Nazas-Aguanaval con un enfoque geográfico}

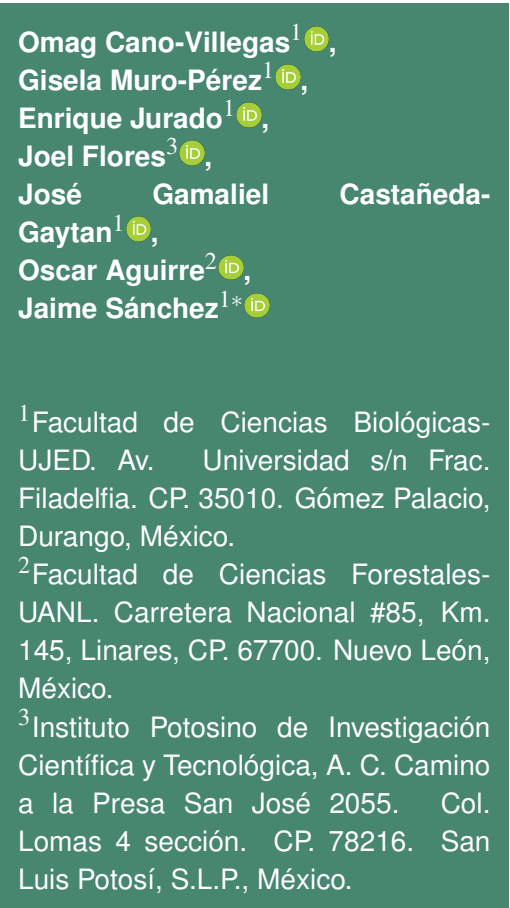

*Corresponding

j.sanchez@ujed.mx

Scientific article

Received: August 7, 2020

Accepted: September 22, 2021

How to cite: Omag Cano-Villegas, Gisela Muro-Pérez, Enrique Jurado, Joel Flores, José Gamaliel Castañeda-Gaytan, Oscar Aguirre, Jaime Sánchez (2021) Trends of climate change at the mid-low NazasAguanaval inland basin based on a geographical approach. Ecosistemas y Recursos Agropecuarios 8(3): e2704. DOI: 10.19136/era.a8n3.2704
ABSTRACT. An integrated geographical climate change evaluation is presented to identify regional patterns of variability in maximum and minimum temperatures, and precipitation at the mid-low Nazas-Aguanaval basin within the States of Durango and Coahuila in Central Northern Mexico by using decadal mean values from 1961-2020. The historical data were acquired from 26 field meteorological stations. The data were organized by the geographical features of elevation, longitude and latitude, and in three groups each. From the overall analysis, the southern and eastern low elevation sites resulted to be the most vulnerable in facing climatic change. By downscaling the meteorological variation, it was possible to improve the understanding of those mechanisms relying on regional climate variability and climate change at a local level. This evaluation can be further incorporated into the management strategies of different stakeholders in arid and semi-arid lands, particularly within the Chihuahuan Desert.

Key words: Arid lands, climate change, geography, meteorological trends, regionalization.

RESUMEN. Se presenta una evaluación integral de cambio climático geográfico para identificar patrones regionales de variabilidad en temperatura máxima y mínima, así como de la precipitación en la cuenca media-baja Nazas-Aguanaval, dentro de los estados de Durango y Coahuila en el centro norte de México, utilizando valores promedio decenales para 1961-2020. Los datos históricos se obtuvieron de 26 estaciones meteorológicas en campo. Los datos se organizaron mediante categorías geográficas de altitud, longitud y latitud en tres grupos cada uno. A partir del análisis general, los sitios con elevación baja, orientación sur y este, resultaron como los más vulnerables ante el cambio climático. Mediante el aumento en la resolución para la variación meteorológica, fue posible mejorar la comprensión de los mecanismos que se basan en la variabilidad climática regional y el cambio climático a nivel local. Esta evaluación puede incorporarse a las estrategias de manejo para diferentes sectores de interés en zonas áridas y semiáridas, particularmente dentro del Desierto Chihuahuense.

Palabras clave: Cambio climático, geografía, regionalización, tendencias meteorológicas, zonas áridas. 


\section{INTRODUCTION}

Climate change is a current issue globally and at the national level for Mexico, with scientific agreement about it (Broecker 2017, Lewandowsky et al. 2019). In this sense, one of the most obvious evidences is that mean temperatures have been increasing on a decadal basis since the second half of the 20th century (Jáuregui 2005, Pavia et al. 2009, Cook et al. 2016, Cuervo-Robayo et al. 2020), accounting for the well-referenced 'global warming'. However, not all sites and locations are affected the same way by the global trends of climatic change, for example, the effect of the urban heat island (Jáuregui 2005), and the inversely buffer or stabilizing effect in highly plant density sites, as well as those with superficial water currents or water bodies (Lobell and Bonfils 2008). Moreover, geographical features, such as elevation, latitude, and longitude may play a key role in determining local climatic trends; thus, the approach of this study is characterizing the behavior of meteorological variables through time, according to the specific conditions present at the Nazas-Aguanaval inland basin, located within the Chihuahuan Desert.

During the period of 1950 - 2000, Brito-Castillo et al. (2009) and Inzunza-López et al. (2011) have reported anomalies regarding the generalized warming trend for Mexico (Pavia et al. 2009) during the period of 1950-2000. These findings (Brito-Castillo et al. 2009, Inzunza-López et al. 2011) pointed out that in some sites at Northern Zacatecas and Western Durango, the actual decadal trends were rather of cooling. These sites are part of the hydrological delimitation called the Northern Central Watersheds (CONAGUA 2021), which in general have a high degree of overexploitation and degradation in terms of the 'health' of the ecosystems within. The Chihuahuan Desert is located between the Sierra Madre systems both east and westwards, and the mean precipitation there is of $250-450 \mathrm{~mm}$ in a year. Given the different general circulation patterns of the oceans (Pacific in the west, and Atlantic in the east) that hit Mexican territory, this area is more accurately related to the Pacific Decadal Oscillation (with a ten- year return period), and EI Niño Southern Oscillation (with a year-to-year return period) (Stahle et al. 2016). Such association can be traced to the historical mega-droughts that took place in the 1950s, 1960s, 1990s, and extraordinary floods in 1958, 1968, 1991-1992, 2008, 2010, 2016 and 2017 (Stahle et al. 2016, Williams et al. 2020). The objective of this study was to identify trends of climate change in the maximum and minimum temperatures and the precipitation at a geographical category level within the Nazas-Aguanaval inland basin, in order to promote adaptation strategies according to the local needs, under the hypothesis that different degrees of meteorological variability could be presented as evidence of climate change for the different localities that make up this region.

\section{MATERIALS AND METHODS}

Climate data from 26 weather stations (within 15 municipalities) of the Irrigation District 017 Comarca Lagunera were acquired from the portal of the National Meteorological System (CONAGUA 2021a), refer to Figure 1 to see the location of the study area in Mexico. The data was originally obtained in a monthly basis, to further calculate yearly and decadal values, covering the period of 1961-2020. Three climatic variables were analyzed: average maximum temperature and minimum temperature, as well as monthly accumulated precipitation (Pavia et al. 2009, Cuervo-Robayo et al. 2020). In an overall approach, without categorizing the data, in order to obtain significant statistical differences a one-way ANOVA ( $P$ $<0.05)$ was performed on the behavior of maximum and minimum temperatures, and precipitation through decadal periods, as main evidences of climate change.

Furthermore, the geographic features of latitude, longitude and elevation were accounted for every meteorological station in order to analyze the behavior of the temperature and precipitation variables related to the geographic gradients. There were three categories set for elevation (Low: 1050 - 1200 masl; Mid: 1300 - 1700 masl; and High: 1730 - 1900 masl), longitude (West: $105.625^{\circ}$ LW 


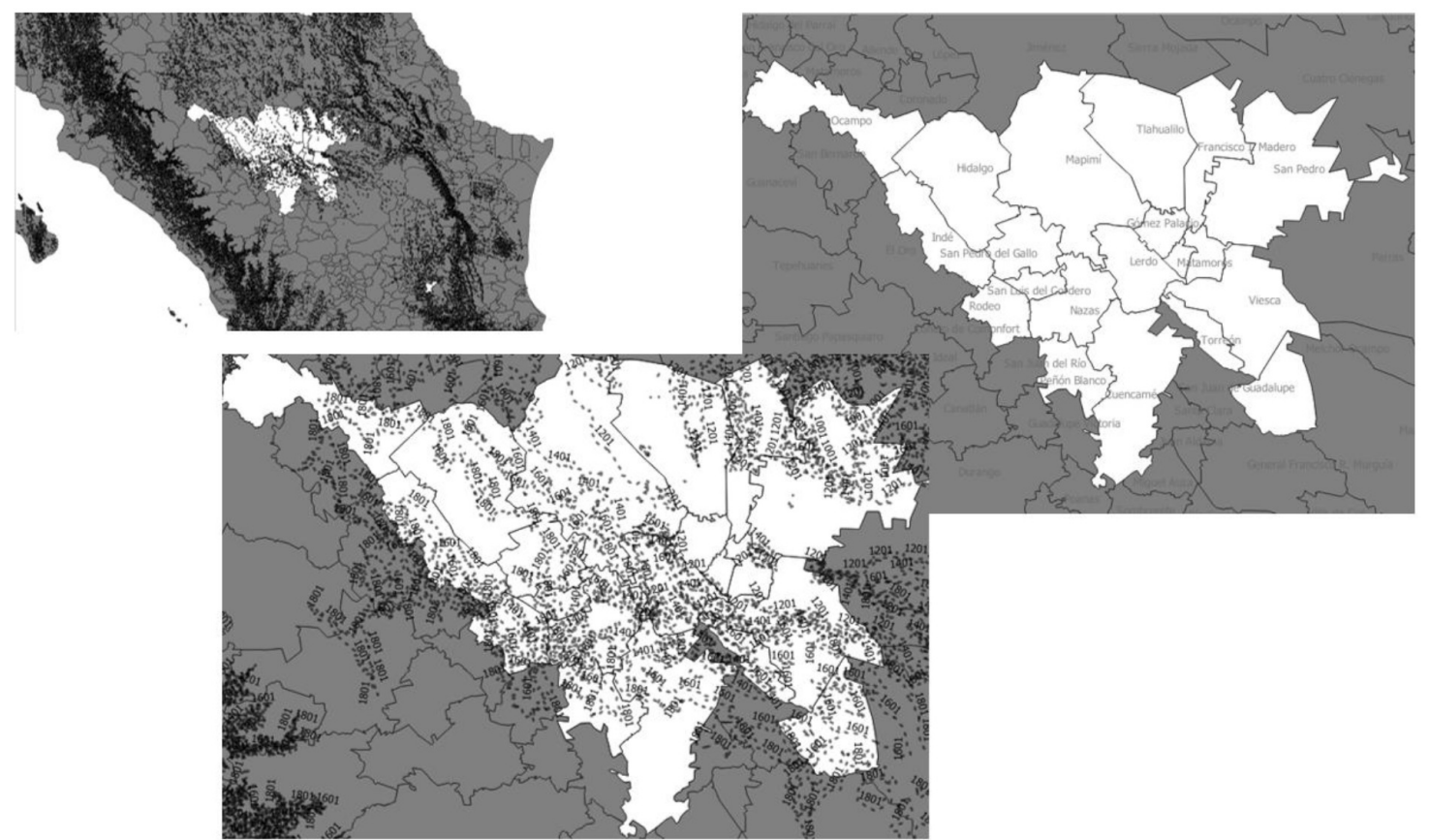

Figure 1. Location map of the study area (white color) indicating the fifteen municipalities (right upper corner) covered in this study within the Nazas-Aguanaval basin, along with elevation levels (center down).

- 104.162 ${ }^{\circ}$ LW; Center: $104^{\circ} 163$ - $103.431^{\circ}$ LW; and East: $103.432^{\circ} \mathrm{LW}-102.8^{\circ} \mathrm{LE}$ ), and latitude (South: $24.61^{\circ} \mathrm{LN}-25.447^{\circ} \mathrm{LN}$; Center: $25.448^{\circ}$ LN - $25.833^{\circ} \mathrm{LN}$; and North: $25.834^{\circ} \mathrm{LN}-26.696^{\circ}$ $\mathrm{LN}$ ), shown in Table 1 , in order to evaluate climate variability at a fine scale (Brito-Castillo et al. 2009, Pavia et al. 2009, Inzunza-López et al. 2011, CuervoRobayo et al. 2020).

To assess vulnerability in every geographical category, a one-way ANOVA was performed to determine significant statistical differences $(P<0.05)$ in the behavior of maximum and minimum temperatures, and precipitation through decadal periods, as main evidences of climate change. Moreover, in order to identify those decadal periods in which the different geographical categories displayed variable conditions (within their counterparts, i.e., high, mid and low elevation), another one-way ANOVA was performed.

The statistical evaluation of the three variables (both with and without geographic categorization) was followed by a Tukey Test means comparison to determine possible statistical groups according to each decade under study (Eakin and Luers 2006). All pro- cedures were performed using the statistical software JMP-SAS (v.15.2.1).

\section{RESULTS}

\section{Six decades of climate sampling}

In the overall approach, accounting all the stations without geographic categorization, the values for maximum and minimum temperature remained relatively constant through the 1961-2020 six-decade period (Figure 2). On the other hand, regarding precipitation levels, the decades of 1981-1990 and 20102020 showed the wettest conditions (1981-1990 being significantly wetter than 1961-1980, and 1991-2000), as shown in Figure 2.

\section{Climate change for the geographical categories within the study area}

There were certain evidences of climate change within elevation categories for temperature. For the maximum temperature, the period of 19912000 was identified as the coldest period in the high elevation category (Figure 3 ). It was also evident that 
Table 1. Weather stations used in the current study, the columns contain information about the station Municipality, years of data, and the three geographic categories of each station.

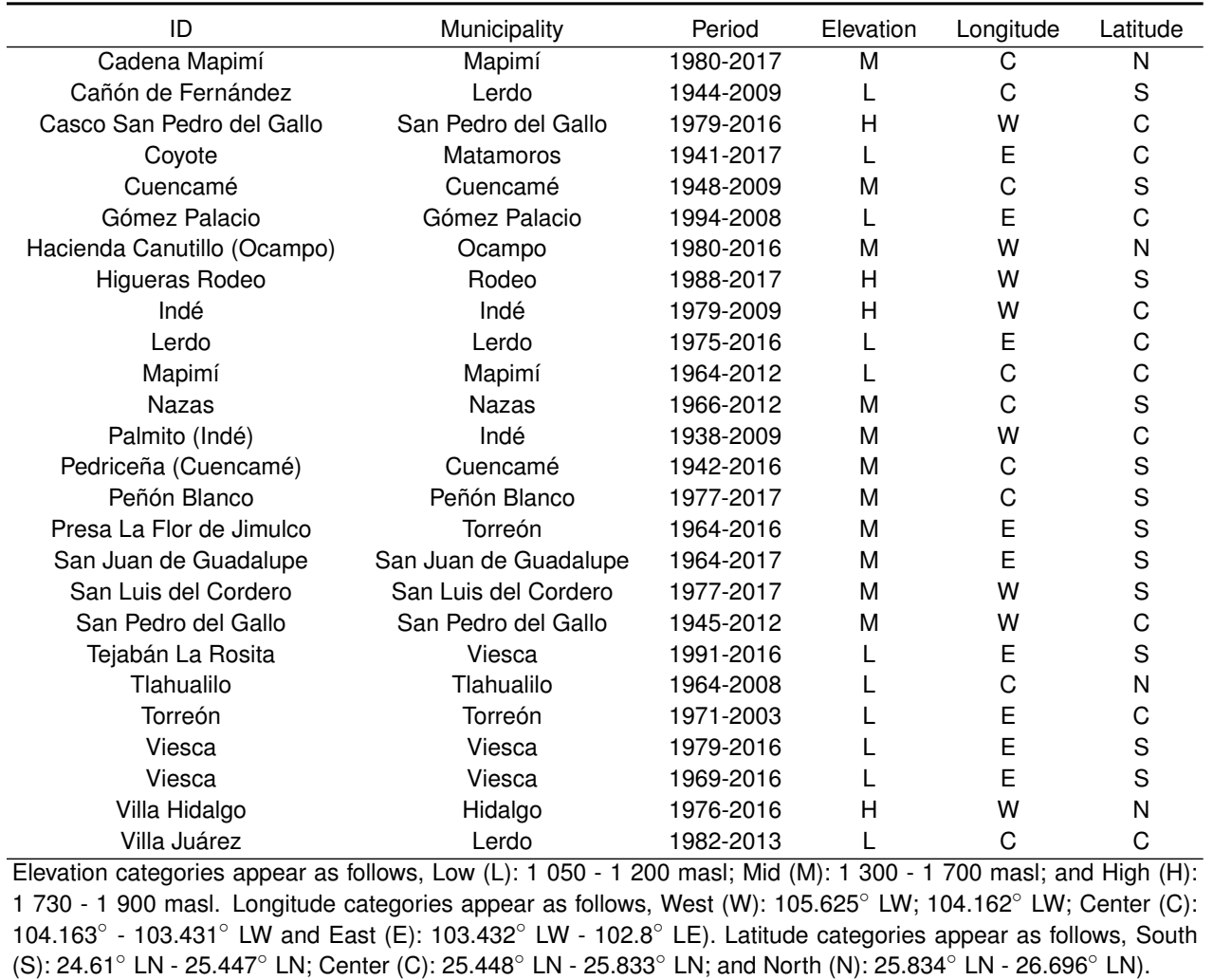

the minimum temperature was significantly variable for the low elevation category, showing a warming trend for the period of 2000-2020. On the other hand, precipitation showed significant variability in all categories (Figure 3). Moreover, for the low and mid elevation categories the wettest period was 1981-1990; while for the high elevation category, the period of 1991-2000 was the driest (Figure 3).

For the longitude categories, maximum temperature remained relatively stable through the sixdecade period. While for minimum temperature, the east category showed a warming trend during 2000-2020. In regards to precipitation, all categories showed 1981-1990 as a wet period; however, 20002020 was also notably wet for the west category (Figure 3).

Maximum temperature remained relatively stable through the six-decade period for all latitude categories. While south latitude was the only category that showed significant variability, displaying a warm period during 2000-2010. For the case of precipitation, all categories displayed $1981-1990$ as a wet period, however, 2010-2020 was remarkably wet for the north latitude category (Figure 3).

Aside from the overall and geographical categories variability, it was possible to identify decadal periods in which there was meteorological variability for certain categories (Table 2). Based on the maximum temperature behavior (which only displayed overall variability within the high elevation category, see Figure 3), during 1961-1970 and 2001-2010 the low elevation category was significantly warmer (than the other categories). While, during 1971-1980, the west category displayed warmer conditions (than the other categories). Regarding latitude, the center category displayed cooler conditions (than the other categories) during 1961-1970.

Regarding the minimum temperature, the low elevation category displayed significant variability and showed the most constant warming trend (among all 


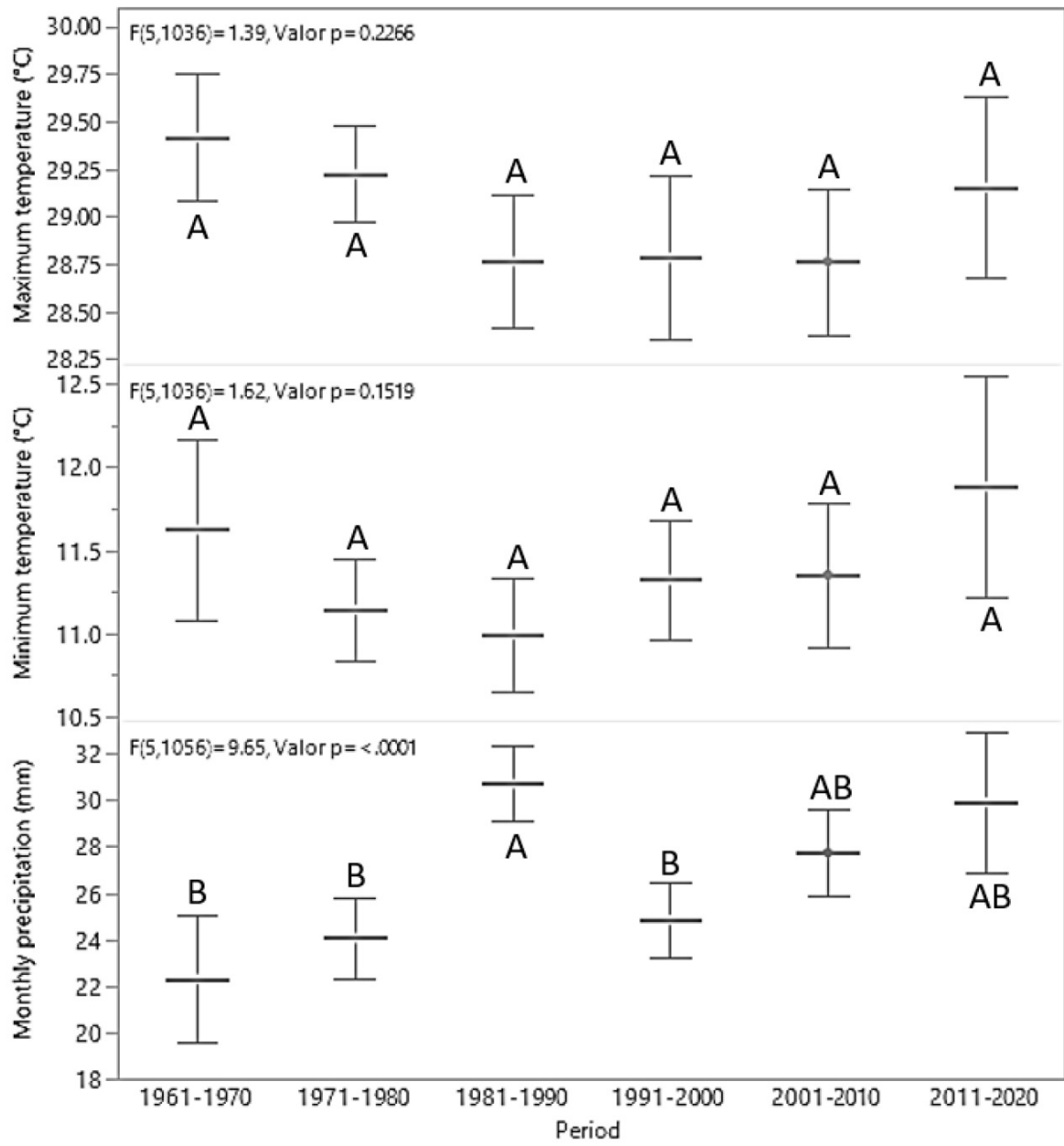

Figure 2. One-way ANOVA for maximum and minimum temperature, and monthly precipitation at the midlow Nazas-Aguanaval watershed for the period of 1961-2020 divided in six decades. Confidence intervals are shown adjacent to mean values. Distinct letters account for different statistical groups from a Tukey test.

geographical categories); the low elevation category was significantly warmer than the other elevation categories during 1991-2020 (Figure 3, Table 3). A similar warming trend was displayed for the east category (which also displayed significant variability within the time periods) during 1981-2020. Comparably, the west category displayed warm conditions during 2011-2020 (Figure 3, Table 3). On the other hand, the south latitude category displayed variability (within the time periods), and the north category displayed cooler conditions (than the other latitude categories) during 1971-1980 and 1991-2020.

Even though precipitation had significant variability, both with and without geographical categories (for all cases), there were specific periods when conditions were either drier or warmer for a given geographical category (Table 2). For elevation categories, the decades of 1971-1980 (only for low elevation), 2001-2010 (in which mid elevation was wetter than high elevation), and 2011-2020 (for all three categories) were wetter (Figure 3, Table 3). On the other hand, 19912000 was the driest decade for all three categories. In the case of longitude, the east category displayed the driest conditions (among the longitude categories) during 1971-2010, while during 2001-2020 the west category was the wettest. Regarding latitude, all three categories displayed similar precipitation values, except for 2011 2020, when the 


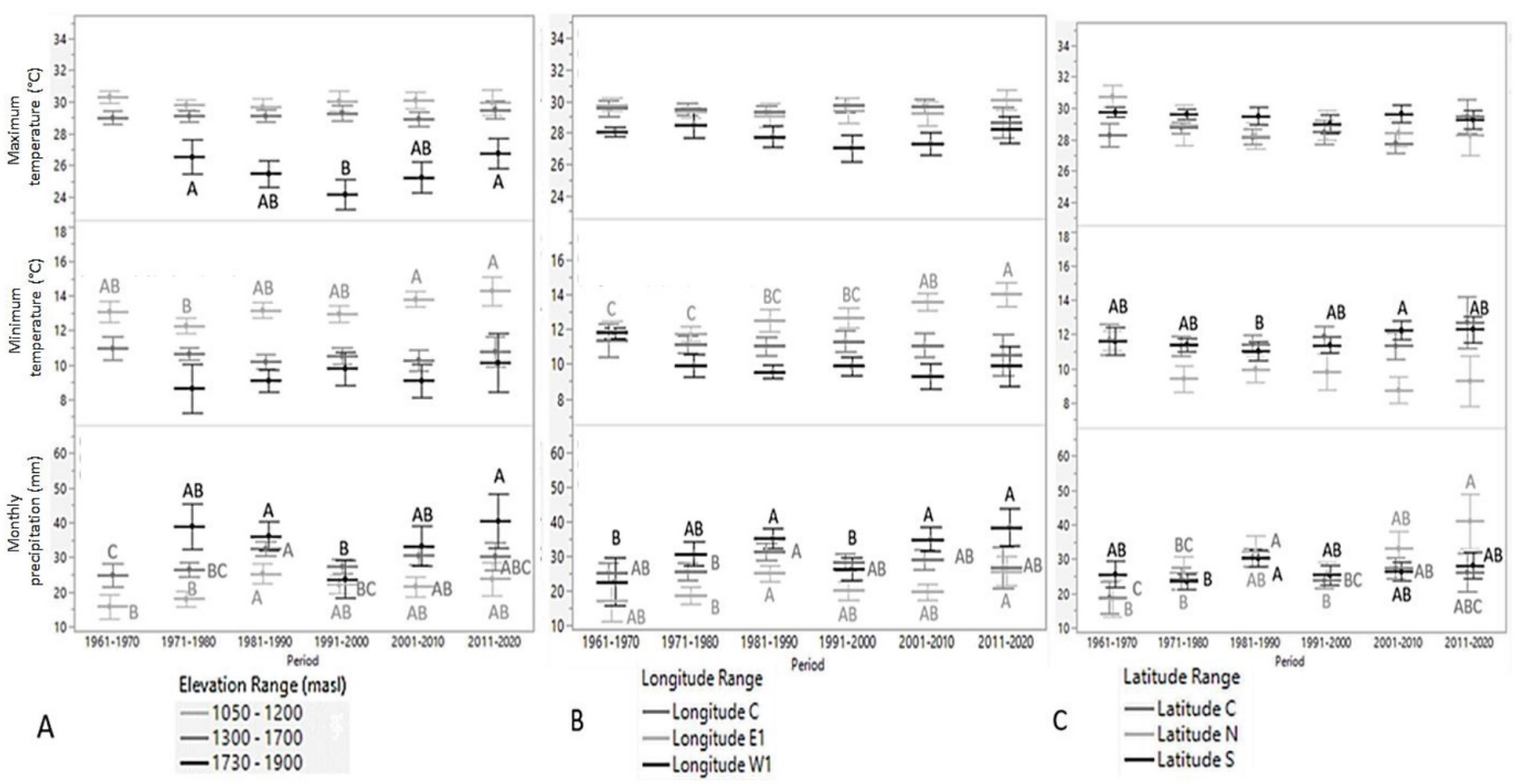

Figure 3. One-way ANOVA for maximum and minimum temperature, and monthly precipitation at the mid-low Nazas-Aguanaval watershed for the period of 1961-2020 divided in six decades. Analyses were performed among the three groups in each category of A) elevation, $B)$ longitude and $C$ ) latitude to evaluate how such physical factors have shaped the climate at a regional scale. Confidence intervals are shown adjacent to mean values. Distinct letters account for different statistical groups from a Tukey test $(P<0.05)$.

Table 2. Results of one-way ANOVA performed to identify significant differences $(P<0.05)$ between geographical categories within each decadal period under study. Grey filled spaces represent non-significant differences.

\begin{tabular}{|c|c|c|c|c|c|c|c|c|c|c|c|c|c|}
\hline & & \multicolumn{2}{|c|}{$1961-1970$} & \multicolumn{2}{|c|}{$1971-1980$} & \multicolumn{2}{|c|}{$1981-1990$} & \multicolumn{2}{|c|}{$1991-2000$} & \multicolumn{2}{|c|}{ 2001-2010 } & \multicolumn{2}{|c|}{$2011-2020$} \\
\hline & & $\mathrm{F}$ & $\mathrm{P}$ & $\mathrm{F}$ & $\mathrm{P}$ & $\mathrm{F}$ & $\mathrm{P}$ & $\mathrm{F}$ & $\mathrm{P}$ & $\mathrm{F}$ & $\mathrm{P}$ & $\mathrm{F}$ & $\mathrm{P}$ \\
\hline \multirow[t]{3}{*}{ ELEVATION } & Maximum temperature & 16.2375 & 0.0001 & 22.0566 & $<.0001$ & 42.4024 & $<.0001$ & 63.3596 & $<.0001$ & 49.0475 & $<.0001$ & 14.9238 & $<<.0001$ \\
\hline & Minimum temperature & 15.606 & 0.0002 & 27.38 & $<.0001$ & 62.1021 & $<.0001$ & 32.2676 & $<.0001$ & 52.6663 & $<.0001$ & 19.4758 & $<.0001$ \\
\hline & Precipitation & 10.0626 & 0.0021 & 26.2632 & $<.0001$ & 12.9433 & $<.0001$ & 4.4791 & 0.0123 & 13.3958 & $<.0001$ & 8.2778 & 0.0005 \\
\hline \multirow[t]{3}{*}{ LONGITUDE } & Maximum temperature & 6.0511 & 0.0038 & 4.252 & 0.016 & 8.6618 & 0.0002 & 16.9267 & $<.0001$ & 15.242 & $<.0001$ & 7.355 & 0.0011 \\
\hline & Minimum temperature & 0.4113 & 0.6644 & 10.2254 & $<.0001$ & 28.1809 & $<.0001$ & 22.3757 & $<.0001$ & 43.5797 & $<.0001$ & 25.1147 & $<.0001$ \\
\hline & Precipitation & 3.3823 & 0.0387 & 17.5878 & $<.0001$ & 13.4649 & $<.0001$ & 9.7102 & $<.0001$ & 26.8627 & $<.0001$ & 8.2822 & 0.0005 \\
\hline \multirow{3}{*}{ LATITUDE } & Maximum temperature & 14.8158 & $<.0001$ & 5.364 & 0.0056 & 7.0477 & 0.0011 & 0.6002 & 0.5495 & 10.686 & $<.0001$ & 1.4981 & 0.2288 \\
\hline & Minimum temperature & 0.011 & 0.989 & 8.6206 & 0.0003 & 4.4903 & 0.0123 & 7.7792 & 0.0005 & 17.2729 & $<.0001$ & 7.4814 & 0.001 \\
\hline & Precipitation & 3.3446 & 0.04 & 0.4025 & 0.6693 & 0.3647 & 0.6948 & 0.5282 & 0.5903 & 3.1366 & 0.0452 & 6.3733 & 0.0025 \\
\hline
\end{tabular}

north category displayed wetter conditions (than in other latitude categories).

\section{DISCUSSION}

\section{Six decades of climate sampling}

In Mexico and worldwide (Pavia et al. 2009, Trenberth et al. 2015, Stahle et al. 2016, Broecker 2017), there was a generalized warming after 1970. For Mexico in general, the increase in temperature has occurred rather in the maximum temperature than in the minimum according to Pavia et al. (2009); it is known that for the Northern State of Zacatecas (BritoCastillo et al. 2009) and the Comarca Lagunera influence area (Inzunza-López et al. 2011) there have been decadal cooling trends for both the maximum and minimum temperatures during the last half of the 20th century. In contrast to all these references, given the analysis of the 26 meteorological stations considered herein, both maximum and minimum mean temperatures remained relatively stable (for 1961-2020), as shown in Figure 2. Regarding the precipitation component, warm North American deserts have displayed episodes of drought and prolonged dry conditions (for 1942-1975, and as of 1999 to present), alternated with relatively wet periods (during 1976-1998), probably due to the intercontinental circulation patterns, such as the Pacific Decadal Oscillation (with a return period of ten years) and the EI Niño Southern Oscillation (with a year-to-year return pe- 
Table 3. Mean values comparison for all three variables under study (maximum and minimum temperature, and monthly precipitation) for six decadal periods from 1961-2020. Distinct letters within the time period columns account for different statistical groups from a Tukey test.

\begin{tabular}{|c|c|c|c|c|c|c|c|}
\hline \multicolumn{2}{|c|}{ Maximum temperature } & $1961-1970$ & $1971-1980$ & $1981-1990$ & $1991-2000$ & $2001-2010$ & $2011-2020$ \\
\hline \multirow[t]{3}{*}{ Elevation } & Low & A & A & A & A & A & A \\
\hline & Mid & B & $\mathrm{B}$ & A & $A$ & $\mathrm{~B}$ & A \\
\hline & High & - & $\mathrm{C}$ & B & $\mathrm{B}$ & $\mathrm{C}$ & B \\
\hline \multirow[t]{3}{*}{ Longitude } & East & A & A & A & A & A & A \\
\hline & Center & $A$ & $A B$ & A & A & A & B \\
\hline & West & $\mathrm{B}$ & B & B & $\mathrm{B}$ & $\mathrm{B}$ & B \\
\hline \multirow[t]{3}{*}{ Latitude } & North & A & $A B$ & B & A & $A B$ & A \\
\hline & Center & B & B & B & A & B & A \\
\hline & South & $A$ & $A$ & A & $A$ & $A$ & A \\
\hline \multicolumn{8}{|c|}{ Minimum Temperature } \\
\hline \multirow[t]{3}{*}{ Elevation } & Low & $A$ & $A$ & A & A & $A$ & A \\
\hline & Mid & B & B & B & B & B & B \\
\hline & High & - & C & C & $\mathrm{B}$ & $\mathrm{B}$ & B \\
\hline \multirow[t]{3}{*}{ Longitude } & East & $A$ & $A$ & A & $A$ & $A$ & A \\
\hline & Center & $A$ & $A$ & B & B & $\mathrm{B}$ & B \\
\hline & West & $A$ & B & C & $\mathrm{C}$ & $\mathrm{C}$ & B \\
\hline \multirow[t]{3}{*}{ Latitude } & North & $A$ & B & B & B & $\mathrm{B}$ & B \\
\hline & Center & A & A & A & A & A & A \\
\hline & South & A & A & $A B$ & A & A & A \\
\hline \multicolumn{8}{|c|}{ Monthly Precipitation } \\
\hline \multirow[t]{3}{*}{ Elevation } & Low & $B$ & C & B & B & $\mathrm{B}$ & B \\
\hline & Mid & A & B & A & A & A & B \\
\hline & High & - & A & A & $A B$ & A & A \\
\hline \multirow[t]{3}{*}{ Longitude } & East & B & $\mathrm{C}$ & B & $\mathrm{B}$ & $\mathrm{C}$ & B \\
\hline & Center & $A$ & $B$ & A & A & B & B \\
\hline & West & $A B$ & A & A & A & A & A \\
\hline \multirow[t]{3}{*}{ Latitude } & North & $A B$ & A & A & A & A & A \\
\hline & Center & B & A & A & A & $A B$ & B \\
\hline & South & A & A & A & A & B & B \\
\hline
\end{tabular}

Elevation categories appear as follows, Low: 1050 - 1200 masl; Mid: 1300 - 1700 masl; and High: 1730 - 1900 masl. Longitude categories appear as follows, West: $105.625^{\circ}$ LW; $104.162^{\circ}$ LW; Center: $104.163^{\circ}-103.431^{\circ}$ LW and East: $103.432^{\circ} \mathrm{LW}-102.8^{\circ} \mathrm{LE}$ ). Latitude categories appear as follows, South: $24.61^{\circ} \mathrm{LN}-25.447^{\circ} \mathrm{LN}$; Center: $25.448^{\circ} \mathrm{LN}-25.833^{\circ} \mathrm{LN}$; and North: $25.834^{\circ} \mathrm{LN}-26.696^{\circ} \mathrm{LN}$ ).

riod) (Hereford et al. 2006, Stahle et al. 2016). Such extreme conditions in turn affect regions of Mexico and the Southwestern United States, and originate the so-called 'North American Monsoon', which is a summer-autumn intense rain season (Adams and Comrie 1997, Stahle et al. 2016, Pascale et al. 2017). However, since the study area is located in the middle of the two Sierra Madre Mountain complexes in Central Northern Mexico, it is geographically 'isolated' and the weather conditions (for example, rain) that hit the coastal areas switch to different intensity after the circulation reaches the mountains, in a phenomenon called orographic rain or shadow (Scheinvar et al. 2020, Zavala et al. 2020). Since the study area has been classified as semi-arid and arid with a precipitation range of 250-450 mm per year (Sánchez-Salas et al. 2014), those areas that are located westwards could get a larger amount of rain than the eastern or central longitude sites; in contrast, southern sites are likely to get drier (than center or north latitudes) in the future (if the trend observed for the period of 2001-2020 continues, see Table 3).

\section{Climate change for geographical categories within the study area}

The reports made by Brito-Castillo et al. (2009), Pavia et al. (2009) and Inzunza-López et al. (2011) in which cooling trends were found for the period of 1950-2000 at some portions of Durango and Zacatecas did not consider specific time periods for the temperature change, instead they presented absolute temperature change rates (it is also noticeable that these studies did not analyze data after the year 2000). Moreover, there was a warming trend country- 
wide for the same period (Pavia et al. 2009, CuervoRobayo et al. 2020); contrariwise, we found some evidences of regional cooling during certain decadal periods. The high elevation category displayed a cooling period during 1991-2000 (in maximum temperature), but after said period, the maximum temperature increased (in this category) and it was even significantly warmer by the 2011-2020 decade (Figure 3). The west longitude category displayed cooler conditions (regarding minimum temperature) than the other longitude categories during 1981-2010 (Table 3). Besides the foregoing, there were notably warming trends for the low elevation (during 1981-2020), the east longitude and the north latitude categories (both during 1991-2020) as evidenced by the minimum temperature. Moreover, Torreón, Coahuila, a city within the categories of low elevation, east longitude and north latitude displayed the highest 'urban heat island' rate for Mexico during the period of 1950-2000 according to mean temperature increases (Jáuregui 2005); for the case of Torreón, both maximum and minimum temperatures showed warming trends for the period of 1961-2020 (data not shown here). Another reference for local warming can be traced to the Mapimí Biosphere Reserve (located within the northeastern part of the study area), which displayed an increase of days per year with temperatures above $40{ }^{\circ} \mathrm{C}$ from 2004-2009 in comparison to 1995-2003, as reported in the Climate Change Action Plan for such Protected Area (CONANP 2014). In this regard, the average maximum temperature did not show significant variability for both the east and north categories, while there were warming trends identified (for minimum temperature during 2001-2020) in said geographical categories in this study. Moreover, a generalized warming could be expected in the future for high elevation and southern sites in terms of maximum temperature (if the trends found here continue). Conversely, in western northern sites with high or low elevations, cooling trends might be prevailing (Table 3), as also reported by Inzunza-López et al. (2011).

Since the focus of this study is a semi-arid region within the desert, processes related to the status of ecosystem degradation include drought, pri- mary production and carrying capacity, soil degradation, water resources and social factors (Hillel and Rosenzweig 2002). Future climate projections for the Nazas-Aguanaval region indicate that in the mid to long term, the area is likely to get warmer (LópezSantos and Martínez-Santiago 2015). However, in a climatic reconstruction for the study region (not shown here) there were two municipalities (Lerdo and Nazas in Durango) that displayed stable conditions for both the maximum and minimum temperatures, probably because of the buffer effect that running water bodies and covering vegetation provide, since these have conserved wetland forests (Lobell and Bonfils 2008). The downscaling of data into a categorization of geographical features, such as latitude, longitude and elevation, made possible to point out different trends in temperature and precipitation changes within this unique semi-arid zone in terms of biodiversity (Sánchez et al. 2014, Barrows et al. 2016). In this sense, a fine scale spatial resolution is needed to adequately capture regional modes in complex orographic basin-based settings. Objectively identified localities can be employed not only in tracking regional climate signatures, but also to improve the understanding of the mechanisms behind regional climate variability and climate change (Abatzoglou et al. 2009).

\section{CONCLUSIONS}

The identification of climate change evidences at a regional and local scales were displayed as meteorological variability in a decadal scale and warming trends, mainly as minimum temperature. This study has potential uses by generating a reference context for the comprehension and management of the extreme meteorological events that represent risk factors in different approaches (like ecosystem and agricultural productivity). In this sense, it would be possible to plan and implement relevant actions for the natural resources management in the face of climate change at a regional level. With the aim of increasing resilience of the local communities, it would be useful to take action especially in those areas that fit into the geographical categories with higher 
variability and warming trends, such as the low elevation, eastern and southern sites. In this manner, by using interdisciplinary research, from the climatological and geographical approaches, it is possible to promote mitigation and adaptation to climate change strategies according to the physical conditions of certain localities.

\section{LITERATURE CITED}

Abatzoglou JT, Redmond KT, Edwards LM (2009) Classification of regional climate variability in the state of California. Journal of Applied Meteorology and Climatology 48: 1527-1541.

Adams DK, Comrie AC (1997) The North American monsoon. Bulletin of the American Meteorological Society 78: 2197-2214.

Barrows CW, Hoines J, Vamstad MS, Murphy-Mariscal M, Lalumiere K, Heintz J (2016) Using citizen scientists to assess climate change shifts in desert reptile communities. Biological Conservation 195: 82-88.

Brito-Castillo L, Díaz-Castro SC, Ulloa-Herrera R S (2009) Observed tendencies in maximum and minimum temperatures in Zacatecas, Mexico and possible causes. International Journal of Climatology: A Journal of the Royal Meteorological Society 29: 211-221.

Broecker W (2017) When climate change predictions are right for the wrong reasons. Climatic Change 142: 1-6. DOI: 10.1007/s10584-017-1927-y.

CONAGUA (2021) Normales climatológicas por estado. https://smn.conagua.gob.mx/es/climatologia/informacionclimatologica/normales-climatologicas-por-estado. Date of consultation: May 21, 2021.CONAGUA (2021) Programa contra Contingencias Hidráulicas - Cuencas Centrales del Norte. https:/www.gob.mx/conagua/ acciones-y-programas/cuencas-centrales-del-norte. Date of consultation: May 21, 2021.

CONANP (2014) Programa de Adaptación al Cambio Climático del Complejo Cuenca Mapimí. https://www.gob. mx/cms/uploads/attachment/file/247260/PACC_Mapimi.pdf. Date of consultation: May 21, 2021.

Cook J, Oreskes N, Doran PT, Anderegg WR, Verheggen B, Maibach EW, Carlton JS, Lewandowsky S, Skuce AG, Green SA, Nuccitelli D, Jacobs P, Richardson M, Winkler B, Rice K (2016) Consensus on consensus: a synthesis of consensus estimates on human-caused global warming. Environmental Research Letters 11: 048002. http://dx.doi.org/10.1088/1748-9326/11/4/048002

Cuervo-Robayo A P, Ureta C, Gómez-Albores M A, Meneses-Mosquera A K, Téllez-Valdés O \& Martínez-Meyer $E$ (2020) One hundred years of climate change in Mexico. Plos one 15(7): e0209808. DOI: 10.1371/journal.pone.0209808.

Eakin H, Luers A L (2006) Assessing the vulnerability of social-environmental systems. Annual Review of Environment and Resources 31: 365-394. https://doi.org/10.1146/annurev.energy.30.050504.144352

Hereford R, Webb RH, Longpré $\mathrm{Cl}$ (2006) Precipitation history and ecosystem response to multidecadal precipitation variability in the Mojave Desert region, 1893-2001. Journal of Arid Environments 67: 13-34

Hillel D, Rosenzweig C (2002) Desertification in relation to climate variability and change. In Advances in Agronomy 77: 1-38. DOI: 10.1016/S0065-2113(02)77012-0.

Inzunza-López JO, López-Ariza B, Valdez-Cepeda RD, Mendoza B, Sánchez-Cohen I, García-Herrera G (2011) La variación de las temperaturas extremas en la 'Comarca Lagunera' y cercanías. Revista Chapingo Serie Ciencias Forestales y del Ambiente 17: 41-61.

Jáuregui E (2005) Possible impact of urbanization on the thermal climate of some large cities in México. Atmósfera 18: 249-252. 
Lewandowsky S, Cook J, Fay N, Gignac GE (2019) Science by social media: Attitudes towards climate change are mediated by perceived social consensus. Memory \& Cognition 47: 1445-1456.

Lobell DB, Bonfils C (2008) The effect of irrigation on regional temperatures: A spatial and temporal analysis of trends in California, 1934-2002. Journal of Climate 21: 2063-2071.

López-Santos A, Martínez-Santiago S (2015) Use of two indicators for the socio-environmental risk analysis of Northern Mexico under three climate change scenarios. Air Quality, Atmosphere \& Health 8: 331-345.

Pascale S, Boos WR, Bordoni S, Delworth TL, Kapnick SB, Murakami H, Vecchi GA, Zhang W (2017) Weakening of the North American monsoon with global warming. Nature Climate Change 7: 806-812.

Pavia EG, Graef F, Reyes J (2009) Annual and seasonal surface air temperature trends in Mexico. International Journal of Climatology: A Journal of the Royal Meteorological Society 29(9): 1324-1329. https://doi.org/10. 1002/joc. 1787

Sánchez J, Estrada-Castillón E, Montes SA, Pérez GM, García-Aranda M, García-Morales LJ (2014) Diversidad cactoflorística de la zona árida y semiárida de Durango, México. Interciencia 39: 794-802.

Scheinvar E, Gámez N, Moreno-Letelier A, Aguirre-Planter E, Eguiarte LE (2020) Phylogeography of the Chihuahuan Desert: Diversification and Evolution Over the Pleistocene. In: Mandujano M, Pisanty I, Eguiarte L (eds). Plant diversity and ecology in the Chihuahuan Desert. Cuatro Ciénegas Basin: An endangered hyperdiverse oasis. Springer, Cham. Switzerland. 19-44.

Stahle DW, Cook E R, Burnette DJ, Villanueva J, Cerano J, Burns JN, Szejner P (2016) The Mexican Drought Atlas: Tree-ring reconstructions of the soil moisture balance during the late pre-Hispanic, colonial, and modern eras. Quaternary Science Reviews 149: 34-60

Trenberth K E (2015) Has there been a hiatus? Science 349: 691-692.

Williams AP, Cook ER, Smerdon JE, Cook BI, Abatzoglou JT, Bolles K, Baek SH, Badger AM, Livneh B (2020) Large contribution from anthropogenic warming to an emerging North American megadrought. Science 368: 314-318.

Zavala V, Carretier S, Bonnet S (2020) Influence of orographic precipitation on the topographic and erosional evolution of mountain ranges. Basin Research 32(6): 1574-1599. https://doi.org/10.1111/bre.12443 